\title{
"Pracować nad lepszą przyszłością". W sprawie raportu Światowej Komisji ds. przyszłości pracy (MOP)
}

\author{
"Work for a Brighter Future". On the report \\ of the World Commission for the future of work (ILO)
}

\author{
dr hab. Irena Boruta
}

\begin{abstract}
Streszczenie Raport Światowej Komisji ds. przyszłości pracy, zatytułowany „Pracować nad lepszą przyszłością”, który będzie stanowił kanwę tegorocznej debaty Konferencji Międzynarodowej (czerwiec), świętującej przypadające w tym roku stulecie Międzynarodowej Organizacji Pracy, zdaniem autorki nie do końca spełnia pokładane w nim oczekiwania. Po pierwsze, nie bierze się w nim pod uwagę ewentualności jaką jest schyłek pracy w następstwie cyfryzacji. W konsekwencji nie porusza się kwestii przygotowań świata pracy do tego schyłku. Po drugie, wątpliwości budzi identyfikacja istotnych, współczesnych problemów pracy, zwłaszcza dlatego, że w raporcie pomija się lub traktuje fragmentarycznie takie problemy, jak skutki globalizacji (ucieczka od prawa socjalnego, rozrost nierówności, specyficzne ruchy na rynku pracy) czy kondycja prawa socjalnego (w tym konieczność dostosowania go do współczesności). Po trzecie, Swiatowa Komisja nie podniosła kwestii skuteczności MOP, operującej jako organizacja międzynarodowa w otoczeniu globalnym, mimo iż stawką tej skuteczności jest wywiązanie się z powierzonych jej zadań, a tym samym jej przetrwanie.
\end{abstract}

Słowa kluczowe: przyszłość pracy, praca w przyszłości, koniec pracy, cyfryzacja, sztuczna inteligencja, współczesne problemy pracy.

Summary The report of the World Commission for the future of work (set up ad hoc by the ILO), entitled "Work for a Brighter Future", does not fully meet the expectations set in it. First of all, it does not take into account the eventuality of the end of work (because of digitization). Therefore, the issue of preparing the world of work until the end of work is in no way open. Secondly, there is doubt about the diagnosis of important, contemporary problems of work. The problems, also neglected or treated in a fragmentary way, are: the impact of globalization on labor, the condition of social law (including the need to adapt it to modern conditions). Thirdly, the World Commission did not raise the issue of the effectiveness of the ILO operating as an international organization in the global environment, although this efficacy is the condition of the fulfillment of the tasks entrusted to her and is condition of the survival of ILO.

Keywords: future of work, work in the future, end of work, digitization, artificial intelligence, contemporary problems of work.

JEL: K31

Str. 2-10

\section{Bibliografia}

Atkinson, A. B. (2017). Nierówności. Co da sięzrobić? Warszawa: Wydawnictwo Krytyki Politycznej.

Baamonde, M. C. (2017). Une vraie solidarité européenne post-crise? (w ramach kolokwium zorganizowanego przez College de FranceRevister les solidarités en Europe), https/filesender.renater.fr/?=downlad\&token=4dacdc22-48e8-15b1$05 \mathrm{f} 67 \mathrm{dca} 2 \mathrm{c} 56328 \mathrm{a}$

Ćwiklak, D. Gajek, M. (2019). My i technologia. Ludzie cyborgi. Tajemnice przyszłości. Newsweek Polska, (1). Ford, M. Świt robotów. Czy 
sztuczna inteligencja pozbawi nas pracy? CDP.

Gilder, G. (2016). Wiedza i władza. Poznań: Wydawnictwo Zysk i Spółka.

Griffin, E. (2018). The industrial revolution: interpretation from 1830 to the Present, https://www.academia.edu/1843995/The...rpretations_from_1830_to_the_present (15.10.2018).

Guerot, U. (2017). Wojna domowa. Warszawa: Wydawnictwo Krytyki Politycznej.

Harari, Y. N. (2018a). Algorytmy nowych wojen. Forum, (26).

Harari, Y. N. (2018b). Homo deus. Krótka historia jutra. Kraków: Wdawnictwo Literackie.

Harrari, Y. N. (2018c). 21 lekcji na XXI wiek. Kraków: Wydawnictwo Literackie.

Hawking, S. (2018). Krótkie odpowiedzi na wielkie pytania. Poznań: Zysk i S-ka Wydawnictwo.

Holley, P. (2017). Why Stephen Howking belive next 100 years may be humanity toughest, test, https://www.washingtonpost.com

Jagoda, A. Klimczak, M. (2011). Praca jako zasób - pojęcie pracy i jej znaczenie. Acta Universitatis Nicolai Copernici, Ekonomia XLII - nauki humanistyczno-społeczne, (402), https://doi.org/10.12775/AUNC_ECON.2011.011.

Księżyk, M. (2004). Globalizacja a rynek pracy z uwzględnieniem Polski, ur.edu.pl.

Kurzweil, R. (2005). The Singularity is Near. New York: Viking.

Kurzweil, R. Vernor, V. (1993). The Coming Technological Singularity: How to Survive in the PostHuman Era.

Lindenberg, G. (2018). Ludzkość poprawiona. Jaknajbliższe lata zmienia świat, w którym żyjemy. Kraków: Wydawnictwo Otwarte.

Marconi, F. (2019). Czy sztuczna inteligencja wspomoże dyktatury. Youval Noah Harari o nadchodzacej rewolucji. Przedruk z „The Wall Street Journal"+wyborcza.pl.

Michalski, C. (2019). Obrona zachodu. Newsweek Polska, (3).

Pikiety, T. (2015). Kapitat w XXI wieku. Warszawa: Wydawnictwo Krytyki Politycznej.

Polus, A. (2010). Kryzysteorii stosunków międzynarodowych w dobie globalizacji, www.kgh.uni.wroc.pl/files/14kgh8polus.pd

Rauflff, U. (2017). Farewll to the Horse. The Final Century of Our Relatonchip. London.

Rifkin, J. (1995). End of work. New York.

Rifkin, J. (2016). Spoleczeństwo zerowych kosztów krańcowych. Internet przedmiotów. Ekonomia wspóldziałania. Zmierzch kapitalizmu. Warszawa: Studio Emka.

Słowik, P. (2018). Robota przy kodeksie, czy robot w pracy. Gazeta Prawna z 5-7 października 2018, B24.

Stigliz, J. S. (2005). Globalizacja. Warszawa: Wydawnictwo Naukowe PWN.

Supiot, A. (2013). Grandeur et la misère de l'état social College de France/Fayard.

Supiot, A. (2014). Qu'est-ce qu'un régime de travail réellement humain? Universite PSL, Conférence du cycle pluridisciplinaire d'études supérieures (CPES).

Supiot, A. (2016). Au delà del'emploi. Le Rapport Supiot, une nouvelle edition.

Tegemark, M. (2018). Life 3.0, https://nickbostrom.com/papers/survey.pdf 